CHAPTER 30

\title{
The Use of Birch Bark
}

\author{
Lucie Fletcher, Nicky Milner, Maisie Taylor, Michael Bamforth, \\ Shannon Croft, Aimée Little, Diederik Pomstra, Harry K. Robson \\ and Becky Knight
}

\section{Introduction}

Birch (Betula sp.) bark is a versatile multipurpose material that has been utilised by hunter-gatherers across the globe in many ways, including food preparation and storage, construction material for mats, lining storage pits, shelter, transportation, baby care, fishing net floats, paper, decorative items, grave goods, medicine and as a source of adhesive. These functions and many others have been documented in the ethnographic and archaeological record (Vogt 1949; Croft and Mathewes 2014).

The birch bark that was uncovered during the recent excavations was typically extremely fragile and easily subject to damage. The bark of birch trees possesses lenticels: small corky elongated horizontal structures where a minimal amount of gas exchange occurs. The lenticels were still visible on all the birch bark artefacts examined, although some were disintegrated, leaving only their outline in the bark. Authigenic crystal growth was visible with the naked eye on several bark artefacts. Based on microscopic observations of a small sample of the crystals removed from the bark, the crystals are consistent with microcrystals previously identified with confocal Micro-Raman spectroscopy as gypsum (Croft 2017). Microscopic analysis of a resin-impregnated and cross-sectioned birch bark roll also revealed framboidal pyrite and fungal hyphal growth between the layers of birch bark. Together, these mineral and fungal factors have acted to delaminate and degrade the condition of the bark.

However, despite the issues with deterioration, a number of interesting discoveries were made: a possible mat composed of layers of birch bark, a possible container, two composite torches, 30 pieces of birch bark as well as 161 birch bark rolls (Figure 30.1). The first three artefacts are significant because artefacts such as these were not identified during the original excavations undertaken by Clark. The recovery and detailed examination of the birch bark rolls has also been important, largely because Clark had not recorded charring on any of the birch bark rolls that he found. However, $41 \%$ of the birch bark rolls, including those held in museums from the original excavations, exhibited signs of charring. This chapter presents the analysis of the birch bark, experimental work and the wider context for birch bark artefacts in the European Mesolithic record.

\footnotetext{
How to cite this book chapter:

Fletcher, L., Milner, N., Taylor, M., Bamforth, M., Croft, S., Little, A., Pomstra, D., Robson, H. K. and Knight, B. 2018. The Use of Birch Bark. In: Milner, N., Conneller, C. and Taylor, B. (eds.) Star Carr Volume 2: Studies in Technology, Subsistence and Environment, pp. 419-435. York: White Rose University Press. DOI: https://doi.org/10.22599/book2.p. Licence: CC BY-NC 4.0
} 


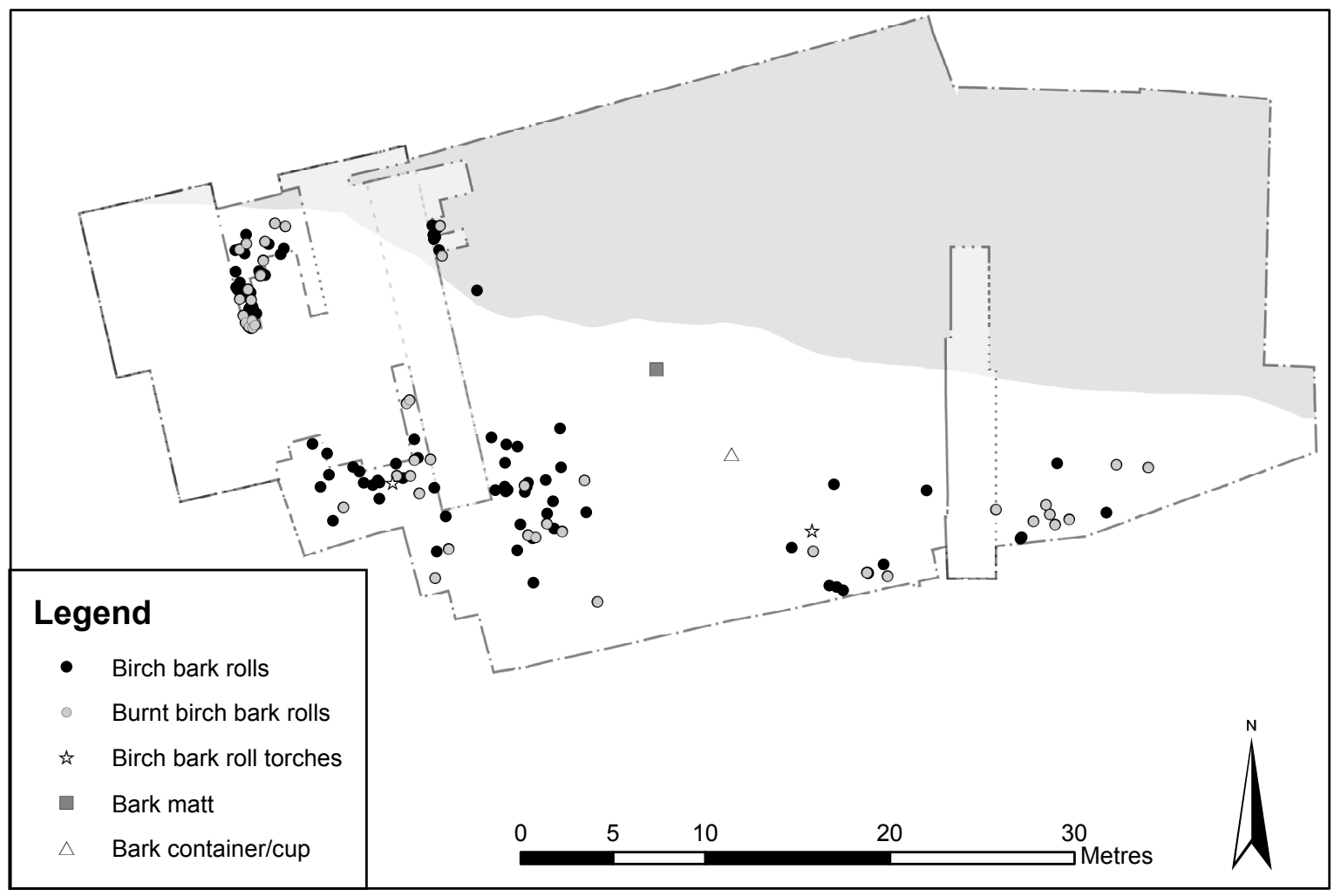

Figure 30.1: Distribution map of artefacts across the site (Copyright Star Carr Project, CC BY-NC 4.0).

\section{Previous analysis}

In the original excavations a number of birch bark rolls were excavated, though we do not know the actual quantities. Clark may have found more birch bark artefacts, which may not have been retained (as noted for other artefacts when the backfill was excavated, see Chapter 7) or are housed in other museums (as the assemblage was further dispersed through loans). In our original collation of museum data (Milner et al. 2013b), only 40 birch bark rolls and small pieces of bark were catalogued. Since then, LF visited a number of museums and catalogued the birch bark rolls that were available for study: the majority $(n=38)$ of the collection is stored in Scarborough with several now on display in the Rotunda Museum; three are stored in The Yorkshire Museum (one of which is on display); two are on display at Whitby Museum; three are stored in the Museum of Archaeology and Anthropology, Cambridge (MAA) and three are stored in the Natural History Museum (NHM). This brings the total to 49. Since then, two more have been noted as being on display in the British Museum and three more have been found in the Scarborough Museum stores. These latter five are not included in this study.

In the first interim report on the excavations, Clark $(1949,63)$ stated that

'Rolls of birch-bark, varying in width from one to eight inches and tightly rolled abounded in the culture layer. The largest specimen illustrated comprises a strip of bark approximately 30 inches long, representing a band removed from a trunk around 9 inches thick. Birch-bark is stored in similar rolls among the Lapps of the modern birch zone. Among people who did not use pottery birch bark may well have played a leading part as a material for containers ... Professor E. Vogt has argued that the utilisation of birch-bark for this and other purposes by the neolithic lake-villagers of Switzerland carried on a tradition, which probably originated during the birch phase of early Post-glacial times. Here at Seamer we may well have evidence for this, though traces of actual objects made from birch-bark have yet to be found. Similar rolls were noted at Mullerup.' 
Although he did not provide any further information concerning these artefacts, a photograph of five birch bark rolls of varying sizes was included. Furthermore, Clark $(1950,118-119)$ stated the following in the second interim report:

'Many more examples of birch-bark rolls were encountered, though most of these were in a more or less decayed condition. A careful watch was kept for signs of birch-bark with stitch-holes or similar signs of having been utilised to make containers or other equipment, but no indications were noted.'

The most comprehensive account of this class of artefact was provided in the monograph on the site (Clark 1954). The birch bark rolls were described as being tightly wound rolls of bark which varied in size from as small as ' 1 in. in width' to ' 8 in. wide and about $30 \mathrm{in}$. long' [25.4-203 mm in width and $762 \mathrm{~mm}$ long] (Clark 1954, 166). Clark did not provide any further details than this; however, he did consider the ways in which they might have been used. He noted that narrow rolls, shaped like a cigar, have been used as tapers up until recently in parts of Europe. He also observed that 'no certain case of charring has been noted on specimens from Star Carr' (Clark 1954, 166). He further pointed out that birch bark rolls have been used as floats for nets, which was also the interpretation for examples found at the Danish Maglemosian site of Mullerup Syd (Sarauw 1903). A further explanation Clark deems more likely for the larger rolls is that rolling the bark up provides a convenient means of storage, although the bark also naturally curls into loose rolls when it is removed or falls from the tree. He explained how even in present day Europe, birch bark is unwound from trunks and stored in rolls for future use.

Pitts (1979) suggested that the Star Carr birch bark could have played a part in tanning animal hides. Tannins are contained in the inner bark, and along with a mixture of gathered mosses and bracket fungus, this vegetable matter could have been used to create a bath which would help accelerate the rate of enzymatic action, creating a tanning agent. Andresen et al. $(1981,41)$ later suggested that the evidence was inadequate to determine such a use.

However, birch bark is also a useful source of resin, which can be distilled to make tar (a type of adhesive), which has various uses. The most well-recognised use of birch bark tar is as a binding agent for hafting projectiles. At Star Carr we know that tar was used for hafting flint tools because a microlith with tar adhering to it was recovered during the original excavations. In addition, at least five thin, flat 'tar cakes' were also discovered: 'the resin was found caked on charcoal as though spilt in the process of extraction or use' (Clark 1954, 167).

These resin cakes and the tar adhering to the microlith were subsequently analysed by Aveling and Heron (1998). Lipid extracts from the residues were analysed using gas chromatography (GC) and gas chromatography-mass spectrometry (GC-MS), which were compared to modern and Mesolithic birch bark. Aveling and Heron's (1998) secure identification of birch bark tar suggests that there may be other tools in the Star Carr assemblage that contain this adhesive material. Lipids were also extracted from some birch bark rolls sampled by Aveling and Heron (1998) and found to yield spectra more similar to birch bark tar than actual bark. In addition, three birch bark rolls from Star Carr were analysed alongside a sample of peat-buried birch bark from Davenham (Aveling and Heron 1998, 76). They determined that all samples derived from tar formed from the heating of birch bark. Therefore, it is possible that the birch bark rolls represent a waste product from the production of birch bark tar.

\section{Birch at Star Carr}

Three species of birch were present in the immediate environment of Star Carr: the downy birch (Betula pubescens, Ehrhart), silver birch (Betula pendula, Roth) and dwarf birch (Betula nana, Linnaeus), which were identified from macroscopic remains, particularly the catkin fruits (Dark 1998b, 127 and 130 Fig 11.4; Dark $1998 c$, 167). However, the bark can only be harvested from B. pubescens and B. pendula, which possess naturally horizontally peeling bark; the bark of $B$. nana is non-peeling and is unlikely to have been used by Mesolithic peoples. $B$. pendula and $B$. pubescens are closely related species which easily hybridise and were previously grouped into one species by Linnaeus called B. alba (Bean 1976, 427). All birch species possess elongated pores or lenticels on the bark. The bark of both $B$. pendula and B. pubescens is tough, waxy and waterproof, but also flexible and able to be shaped. $B$. pendula (silver birch) bark is shiny, smooth, and silvery-white, with black fissures on the lower trunk of older trees (Hart and Raymond 1973, 6; Godet and Mitchell 1988, 28). 
B. pubescens (downy birch) has bark similar to B. pendula that is more or less smooth throughout, and papery, but is usually grey, yellow, brown or, rarely, white in colour (Elwes and Henry 1909, 962; Clapham et al. 1989, 313; Stace 2010, 293). The colour of the artefacts from Star Carr in general has been altered by peat staining. $B$. pendula and B. pubescens are closely related and the bark exhibits overlapping characteristics that preclude differentiation when bark is examined isolated from the tree. Even when microscopic analysis of the cell structure of birch bark artefacts is undertaken for conservation purposes, the bark is identified only to genus (Florian 1990, 71). Thus, the birch bark artefacts recovered from Star Carr were identified by macroscopic examination to the genus Betula.

When birch bark exfoliates and peels from the tree naturally, it does so in thin layers and small strips, the ends of which are tapered. Birch bark indicative of anthropogenic harvesting exhibits right angles due to people making straight vertical cuts in the bark and it is also often several millimetres thick, traits which do not occur naturally. There were four main criteria that were used to recognise potential birch bark artefacts at Star Carr: right angles, thick bark, tight rolling and charring.

\section{Birch bark container}

What appeared to be a container $<113780>$ was recovered from detrital mud (317), amongst the timbers of the detrital wood scatter (Figures 30.2 and 30.3). The three fragments of bark were in the shape of a small cup or vessel with a maximum diameter of $80 \mathrm{~mm}$ and a height of $75 \mathrm{~mm}$. The bark had a maximum thickness of $1.5 \mathrm{~mm}$ and was orientated cambium/inner face in and cork/outer face out. Cut edges, folds and stitch holes were used by Croft and Mathewes (2014) to identify compressed and fragmentary birch bark containers from British Columbia, Canada, but none of these features were identified here. However, birch bark containers can

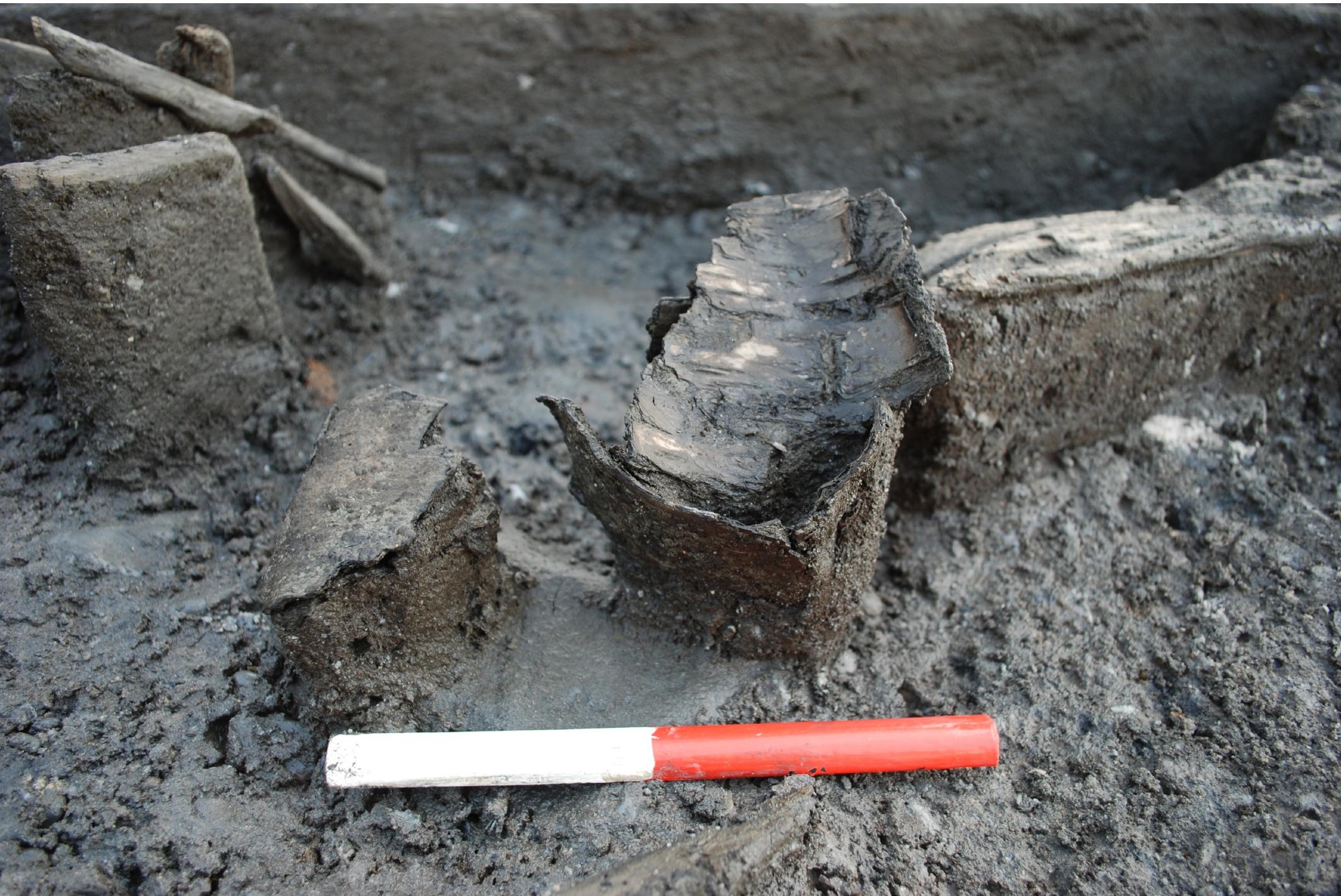



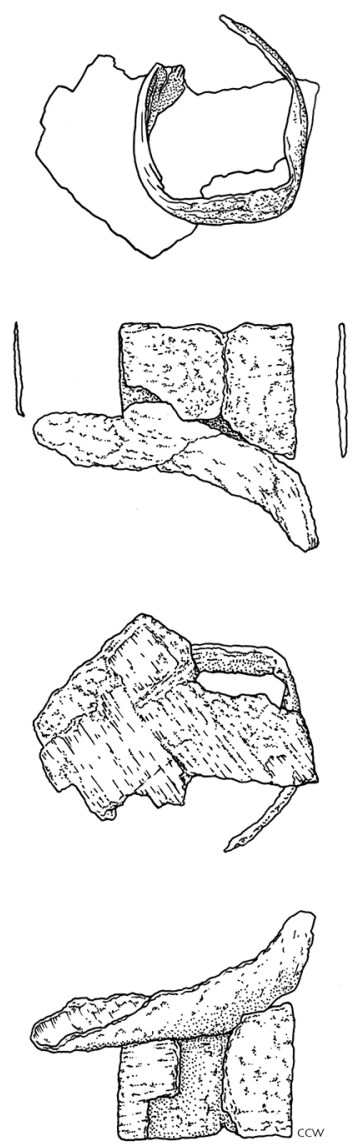

$0.50 \mathrm{~mm}$

Figure 30.3: Possible birch bark container <113780> (Copyright Chloe Watson, CC BY-NC 4.0).

be made by folding and fastening using twigs. It is not clear whether it could have been a container, though the thickness of the bark indicates that it was deliberately harvested.

The oldest known birch bark containers in Northern Europe have been recovered from Friesack IV in Germany and Vis I in Russia (Burov 1998; Gramsch 1992; 1993; 1998; 2016; Gramsch and Kloss 1989): one example from Friesack IV measured $188 \mathrm{~mm}$ in length by $98 \mathrm{~mm}$ in width and was found within a pit which has been interpreted as a water hole or well on the habitation site (Gramsch 1992; Gramsch 2016). Given its location, it could have served as a water filter or to draw the water from the pit (Gramsch 1993; 1998). Further birch bark containers are known from the Boreal sites of Veretye I and Zamostje 2 in Russia (Lozovskaya and Lozovski 2016; Oshibkina 2007). At Veretje I the container was recovered from the top of the old land surface and situated next to the exit of a dwelling. It contained lithics and may be interpreted as a cache (Oshibkina 2007). Four fragments of birch bark are also known from Szczepanki Site 8 in Poland; these had been perforated and may represent two kinds of containers (Gumiński 2012).

\section{Birch bark mat}

\section{Analysis}

A birch bark mat <99307> was recovered in 2013 from the top of the reed peat (312); this would have been wet and potentially periodically flooded (Chapter 19) (Figure 30.4). Measuring $750 \mathrm{~mm} \times 970 \mathrm{~mm}$, the mat was

Figure 30.2 (page 422): Photograph of the birch bark container in situ (Copyright Star Carr Project, CC BY-NC 4.0). 


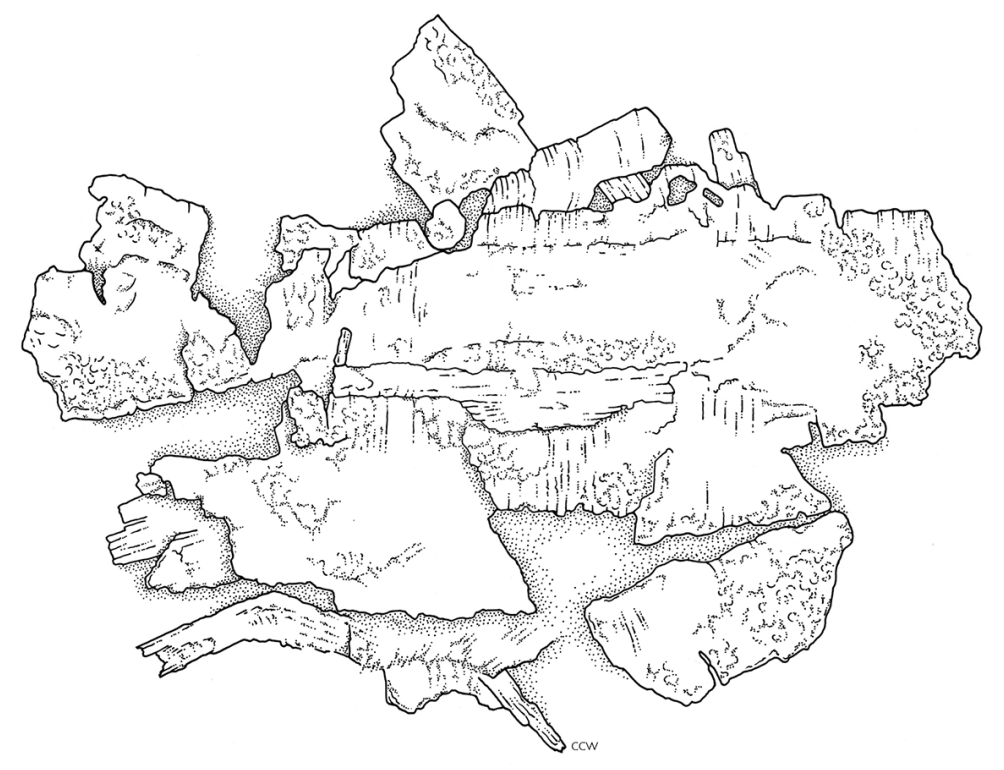

0 $50 \mathrm{~cm}$

Figure 30.4: Illustration of the birch bark mat <99307> in situ that was recovered in 2013 (Illustration by Chloe Watson, after Hayley Saul. Copyright Chloe Watson, CC BY-NC 4.0).

lifted in several blocks and partially micro excavated under laboratory conditions by MT and BK. Several questions were asked in order to determine whether the item represented a cultural artefact:

- Are there multiple layers of bark?

- Is any wood attached to the bark or is it bark alone?

- Is there any evidence that the edges of the bark are cut, either straight or curved?

- Is there any evidence for additional technology such as stitch holes?

Micro-excavation identified four layers of bark, all of which were lying with the inner (cambium) face upwards and the outer (cork) side down:

- Layer A: the top layer of bark was quite fragmented, 1-2 mm thick and could be lifted off quite easily. This layer of bark lay almost directly on top of the next one with approximately $1 \mathrm{~mm}$ of sediment separating them.

- Layer B: the second layer was very thin, less than $1 \mathrm{~mm}$. This layer was in direct contact with the one beneath.

- Layer C: the third layer was very slightly thicker, $2-3 \mathrm{~mm}$. This layer was in direct contact with the one beneath.

- Layer D: the fourth and lowest layer of bark was $2 \mathrm{~mm}$ thick.

The bark has the full bark structure and is definitely not derived from the small, natural curls of bark which some young birch trees develop and naturally shed. Although it was very thin, sometimes barely $1 \mathrm{~mm}$ thick, none of the bark had any trace of bast fibres or sapwood on the inner face. Due to compression and fragmentation it was impossible to reconstruct the original size of each bark fragment and therefore estimate the minimum diameter of the tree from which the bark was harvested. However, given the thinness of the bark, it must be derived from quite a small tree(s). 
Birch bark is more easily harvested in spring, when the sap or phloem is actively running to support new growth of the tree (Turner et al. 1990; Turner 1998). However, this can cause the tree to 'bleed', which will foster disease and/or weaken it. Some of the bark had straight, thickened, edges. It is likely that this thickening is scar tissue caused by regeneration after damage. Although it is impossible to say what caused the damage, it could have been caused by earlier bark removal. If bark is damaged or removed from a tree in such a way that it is not killed, the bark will gradually grow back over the area that was stripped.

Although no cut edges or stitch holes were identified, the presence of four layers of bark, each in the same orientation, with no bast fibres or sapwood adhering to the inner surface, suggests a culturally constructed artefact. The layers of bark seem to form a mat, though it must have been deposited into a fairly wet context (Chapter 19). Flotation samples recovered from the top, working surface of the mat and from the sediment interdigitated between layers A and B did not produce any evidence for its use, i.e. no charred macrofossils or microdebitage. In addition, no obvious activities had taken place in the area around the mat. Therefore, it is not clear what it might have been used for.

\section{Wider context}

In the UK an extensive area of bark flooring was found in Area E1, at the Late Mesolithic site of Williamson's Moss, Cumbria (Bonsall et al. 1989). Here, the flooring was well preserved in places and was 'made of superimposed layers of bark fragments laid down as a dense mat up to $10 \mathrm{~cm}$ thick' (Bonsall et al. 1989, 192). In total, it covered an area greater than $6 \mathrm{~m}$ and was interpreted as the 'remnants of the internal floors of one or more building constructed on the platform and the adjacent land surface' (Bonsall et al. 1989, 192).

Similarly, when bark matting has been discovered in Southern Scandinavia, it has largely been interpreted as the remnants of dwelling-places with flooring, such as examples made from aspen, pine and pine/birch at the Danish sites of Barmosen I, Bara Mosse I, Holmegård IV, Lavringe Mosse, Lundby II, Ulkestrup Lyng I (Becker 1945, Grøn 2003; Sørensen 1987). Other Danish sites include the Early Mesolithic site of Ulkestrup Lyng II where a birch bark floor, measuring $6 \times 4.5 \mathrm{~m}$ in size, was found; 'the floor consisted of bundles of branches, twigs, remains of leaves, and leaves of Marsh Fern' (Andersen et al. 1982; Grøn 2003, 686). The Late Mesolithic, Ertebølle culture site of Møllegabet II, Denmark, produced a bark layer with twigs and bracken leaves measuring $5.2 \times 3.2 \mathrm{~m}$ in size with a depth of up to $200 \mathrm{~mm}$. The presence of stakes around its edge as well as two hearth zones strengthened the argument that this was used as a dwelling (Grøn 2003; Grøn and Skaarup 1995). Similarly, at the Late Mesolithic site at Smakkerup Huse, mats constructed from lime or birch bark were recovered and were interpreted as serving as a floor within structures (Price and Gebauer 2005).

Duvensee in Germany is perhaps the most renowned Early Mesolithic site that has yielded matting (Chapter 12). A total of six bark mats made from either birch, aspen or pine were recovered over the course of excavations in the Duvensee peat bog: Duvensee $1(n=2)$, Duvensee $2(n=1)$, Duvensee $6(n=1)$, Duvensee $8(n=1)$ and Duvensee $13(n=1)$. Some of these were found on top of one another, whilst at one site, the lowest lay on top of a 'platform made up of twigs and thick, straight branches' (Grøn 2003, 686). The majority of these mats measured $4 \times 4 \mathrm{~m}$ in size (Bokelmann 1971; 1975-7; 1983; 1986; 1989; Bokelmann et al. 1981; Holst 2010), with the largest measuring at least $6 \mathrm{~m}^{2}$ (Holst 2010, 2873). Of these, at least two have been interpreted as roasting hearths and had been constructed with pine and birch bark (Bokelmann 1975-7; Holst 2010). One of these had a layer of white thick sand (20-140 mm thick) and a mixture of charcoal, hazelnut shells and lithics were recovered from the top of it (Holst 2010, 2873).

Bark mats have also been found at three Late Mesolithic/Early Neolithic sites in Satrupholmer Moor, Germany, although details are lacking as to the species of wood that were used (Feulner 2011). At the site of Rüde LA 2, a compact package of bark mats was found, which consisted of bark pieces that were up to $4 \times 1 \mathrm{~m}$. Feulner (2011) states that they were not specifically positioned but some were found overlapping or at an oblique angle with the majority being orientated north-south. On top of these mats, which covered a total area of around $6 \times 2 \mathrm{~m}$, traces of fireplaces were found (Feulner 2011). Nearby, at the Middle/Late Mesolithic site at Satrup LA 2 Bondebrück, overlapping bark mats were recorded which were up to $5 \mathrm{~m}$ in length. At another nearby locality, Satrup LA 71 Förstermoor, wooden timbers and bark pieces were found which are likely to have served to reinforce the boggy terrain (Feulner 2010; Feulner 2011). Further afield, a birch bark layer has been found at the Middle/Late Sub-Neolithic site of Riihimäki Silmäkeneva E in Finland (Koivisto 2011), whilst a large number of bark floors are known from Sarnate in Latvia (Vankina 1970). 


\section{Birch bark rolls}

\section{Methods}

During the recent excavations, 142 birch bark rolls and small pieces of bark were retained, the vast majority of which were recovered during 2013-2015 in the waterlogged deposits within trench 34 (Figure 30.1). Others were encountered but many were too degraded to be lifted. All 142 rolls and pieces of bark retained from the years 2007, 2013, 2014 and 2015 as well as the 49 held in museum collections were analysed ( $n=191)$. All of the museums were visited with the exception of the Natural History Museum. The examples at Whitby could not be handled because they were on display. In these two cases records have been made from photographs or by observations made by looking through the display cases.

The rolls were catalogued in a spreadsheet (archived in ADS: https://doi.org/10.5284/1041580), and characteristics were noted such as charring and location of charring, whether it was rolled or a piece of bark (as a result of being originally flat, unrolled or broken), and measurements were taken using digital calipers: height (top to bottom when looking end on), width (side to side when looking end on) and length (length from one end to the other). The bark was then examined for evidence of cutting. In some cases it was possible to determine that the birch bark was humanly modified because the bark was thick (about $3 \mathrm{~mm}$ or more), usually cut in a straight line vertically and often tightly rolled; alterations which are not observed in naturally shed bark.

Many of the specimens were extremely fragile and in some cases broken, compressed or flaking to pieces and so not always possible to tell whether it had originally been rolled or not. It was difficult to be sure of charring in every case due to the dark organic peat-staining on the bark surface making it difficult to identify any traces, particularly in cases where the rolls were still wet-packed from excavation. It is also difficult to identify internal charring without taking the rolls apart, though sometimes it is visible externally. Measurements posed a problem particularly in terms of height, where the roll had been compressed by the peat, and so few height measurements were made. In addition, often the height at one end was different to the other, in which case, and where possible, both measurements were recorded. Where there was uncertainty a characteristic was not recorded.

\section{Results}

Of the 191 specimens, 161 rolls and 30 pieces of bark were identified. The pieces of bark varied in size, ranging from fragments to a piece $210 \mathrm{~mm}$ in length. Three pieces of bark showed definite signs of cutting: for example, $<94289>$ is a thick, flat piece of bark which has been cut vertically and cannot have come off a tree in this way naturally (Figure 30.5). Overall, the bark shows no distinct spatial patterning and comes from the dryland, the detrital wood scatter, the bead area (to the north of cutting III), and Clark's area (Figure 30.1).

Of the 161 rolls, 74 were broken. Of the 117 rolls which provided length and width measurements, there was a range of sizes and shapes with some very large pieces of bark as well as some very small pieces (Figure 30.6). None are as long as the largest one found by Clark of 30 inches [c. $760 \mathrm{~mm}$ ] (it is interesting to note that this one was not found in the museum collections). The lengths generally fall below $150 \mathrm{~mm}$, with the majority falling below $100 \mathrm{~mm}$, and the widths are generally smaller than $60 \mathrm{~mm}$ with the majority under $40 \mathrm{~mm}$. A number of the rolls are tightly rolled and some of these have been termed 'cigar-like' (Figure 30.7). In some cases, where the rolls had broken or the ends were in good condition, it was possible to count up to seven or eight layers.

Each specimen was also carefully analysed for evidence of charring. The degree of charring varied and in four cases was very obvious; the bark had turned black and shiny with a crazed or bubbly, honeycomb-like surface. Overall, charring was evident on 66 (41\%) of the rolls with a further eight possible cases. This is a remarkably greater frequency of charring than seen among the wider wood assemblage (3.7\% across the entire assemblage; $5.3 \%$ across the culturally modified assemblage).

Of the charred rolls, four had burning at both ends and all were found in Clark's area. A further 14 were burnt at one end: six from the museum collections that had been recovered during the original excavations, and the rest from reed peat (312), of which four derived from Clark's area, two from the eastern platform and two from the wetland deposits. A total of seven exhibited clear signs of burning within the rolls: two from the Scarborough collections (and so dating to Clark's excavations), two from reed peat in Clark's area, two from wood peat (310) in the area north of cutting III where the beads were found (Chapter 33), and one from the reed peat in 


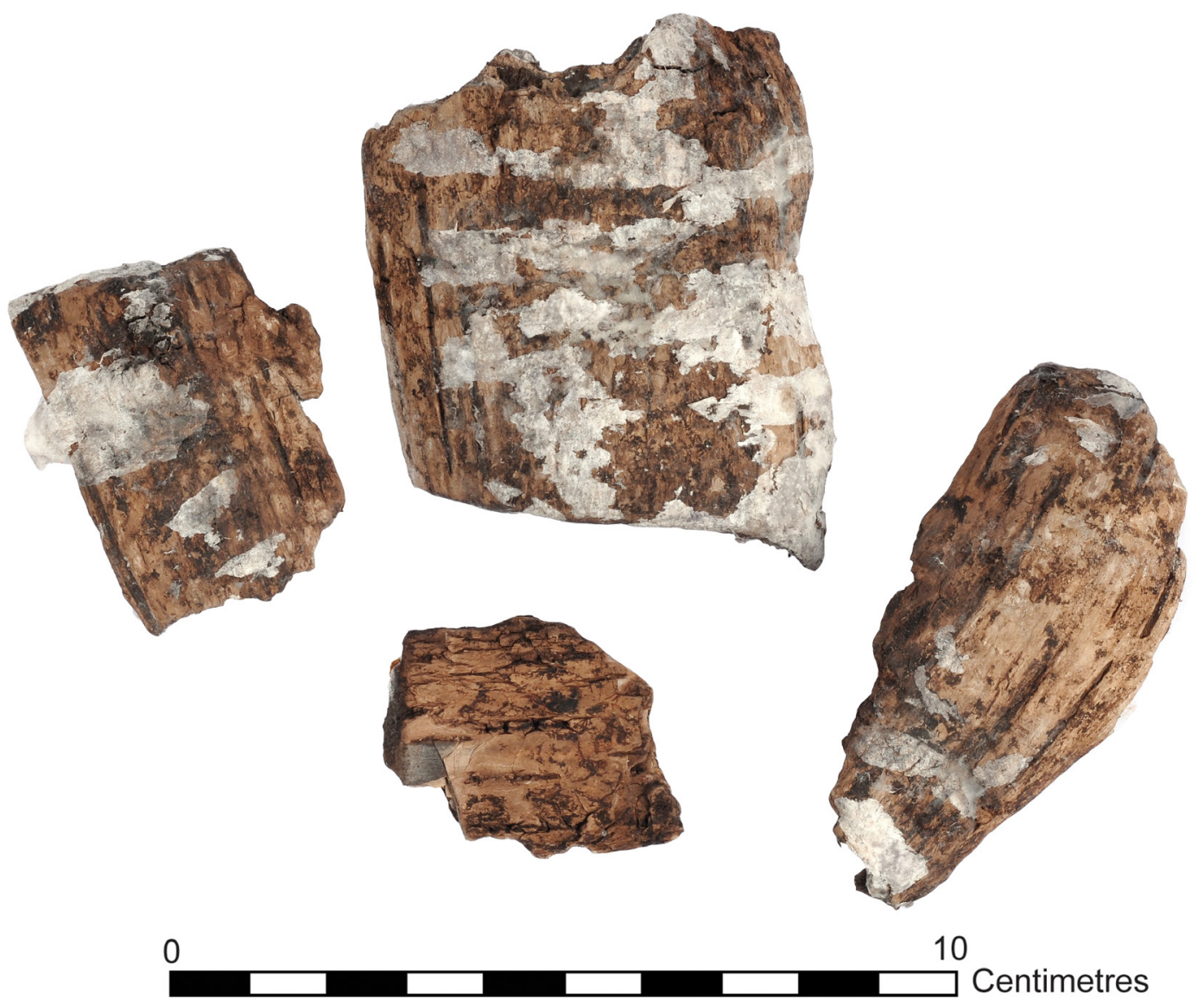

Figure 30.5: Photograph showing thick, cut bark from <94289> (Photograph taken by Paul Shields. Copyright University of York, CC BY-NC 4.0).

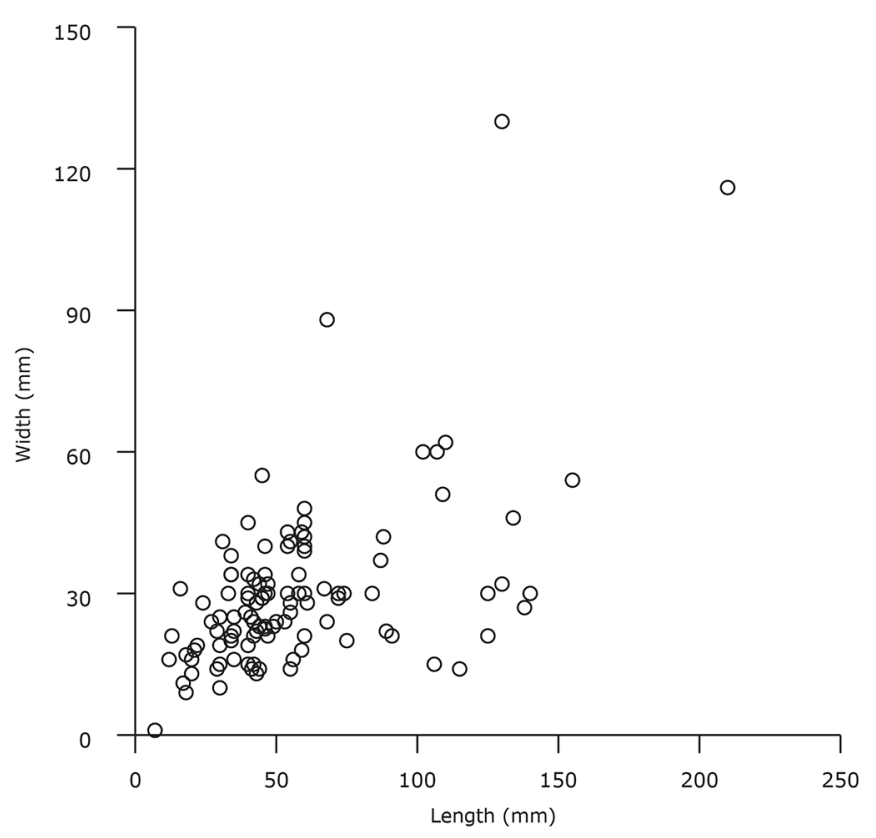

Figure 30.6: Graph showing the length and width of the birch bark rolls that could be measured (Copyright Star Carr Project, CC BY-NC 4.0). 

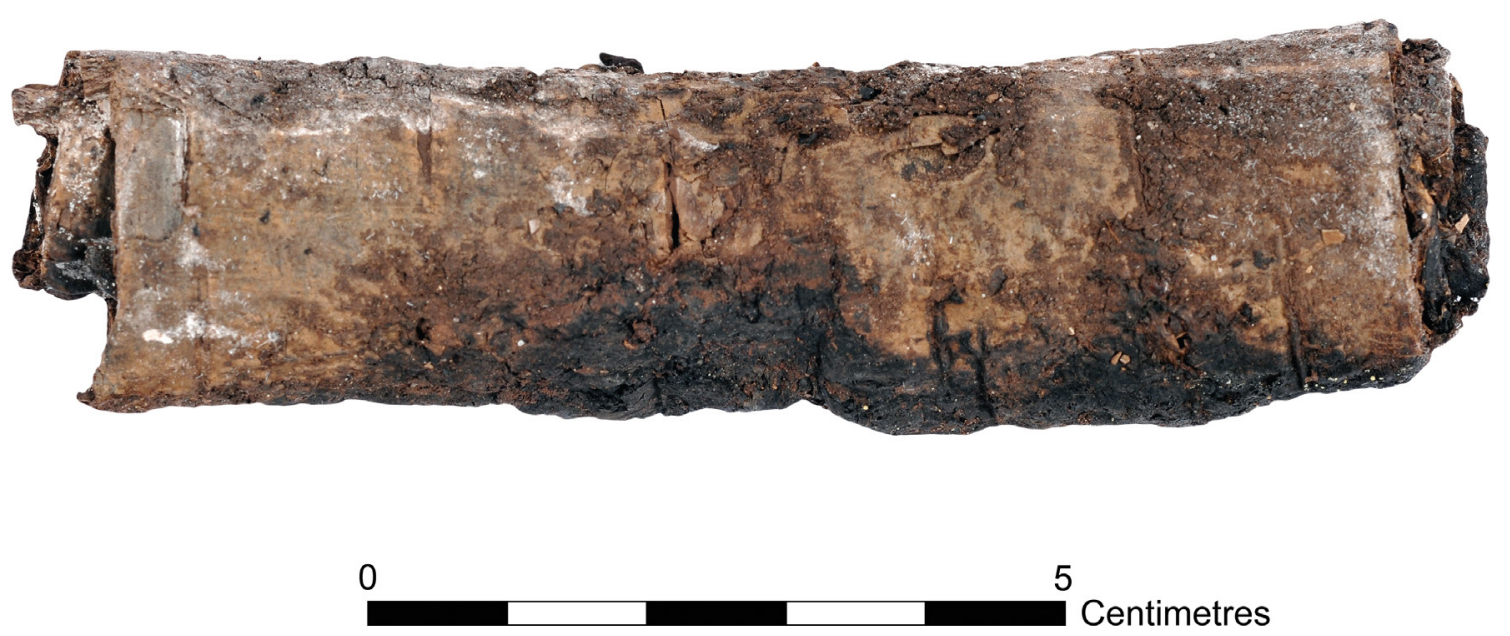

Figure 30.7: Photograph of a 'cigar' type birch bark roll $<115225>$ which also exhibits signs of charring on the lower side (Photograph taken by Paul Shields. Copyright University of York, CC BY-NC 4.0).

the area of the eastern platform. A further three exhibited burning at both one end and inside: lake area wood peat, wood peat in the bead area, and a roll from the Scarborough collection. A further sample was burnt on the outer surface and internally, and this again was a museum sample from The Yorkshire Museum. Nine showed traces of charring on the outer edge: two of these came from reed peat and detritral mud in the detrital wood scatter; two from the wood peat, and one from the eastern platform reed peat; one from Clark's area reed peat; and three from museum collections. All other records of charring were on fragmented pieces.

Overall, the charring shows no clear patterning (Figures 30.1 and 30.8). It occurs across the site and in each area there are similar numbers of rolls which have not been charred. The different types of charring on the birch bark rolls can be explained in a number of ways. Firstly, it is possible that some charring can be attributed to natural or anthropogenic fires across the reed beds, as has been suggested by Dark (1998b). Those birch bark rolls which are heavily charred, or even which have one end charred, could have been naturally occurring birch bark rolls which were charred by accident. It is harder to suggest accidental charring for those which have two ends charred or which exhibit charring inside but not on the outside, many of which have been deposited in Clark's area. The most likely explanations, as already suggested by Clark, are that they were being used as tapers, torches, or for the production of tar.

What is surprising from our recent excavations is the absence of further identifications of birch bark tar, despite conducting extensive residue and microwear analysis across the site. No more 'resin cakes' or macroscopically visible residues on tools have been found since Clark's discoveries (1954), confirmed as originating from birch bark tar by Aveling and Heron (1998). Whether the lack of further birch bark tar discoveries is due to unexplained taphonomic factors or, perhaps more simply, that birch bark tar was not present in the excavated parts of the site is unknown. Amorphous orange-red deposits were found on several lithics during microscopic residue analysis that were hypothesised to be possible resinous residues. However, when tested by chemical characterisation techniques, specifically Micro-Raman and GC-MS, these residues were demonstrated to be mineral in origin, and they were identified securely as iron oxide (Croft 2017). This research provides an important warning against identifying amorphous residues using visual methods only.

\section{Torches}

The examination of the birch bark rolls also led to the discovery of two multiple component torches. These are composed of a stick with birch bark wound around one end, with clear evidence for combustion of the bark. The locations of fire exposure on these artefacts and appearance of carbonisation is unmistakable, with shiny black colouration, and fragile bubbly honeycomb appearance where the fire was alight. 


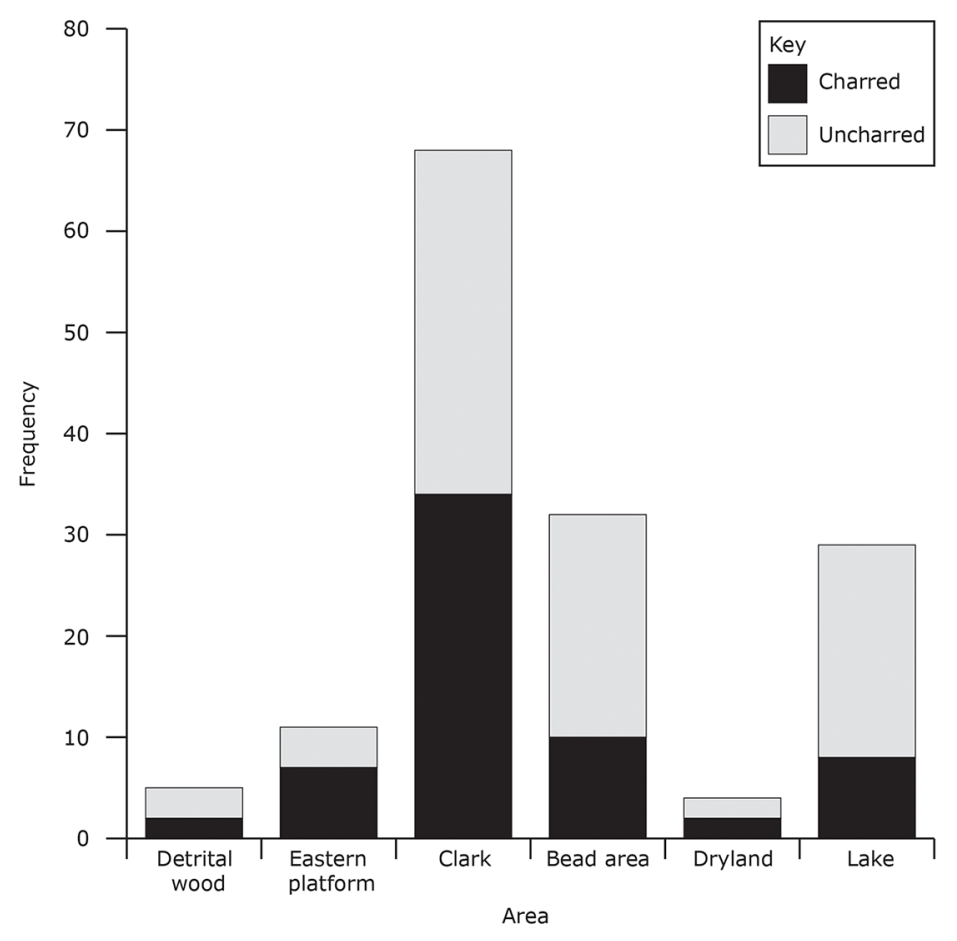

Figure 30.8: Graph showing the distribution of charred and uncharred birch bark rolls found at Star Carr (Copyright Star Carr Project, CC BY-NC 4.0).

$<115628>$, recovered from Clark's area, was wrapped around a small length of roundwood identified as aspen (Populus sp.) (Figures 30.9 and 30.10). The roundwood was moderately charred, broken at both ends and measured $41 \times 19 \times 17 \mathrm{~mm}$. A further possible torch is $\langle 107756\rangle$, which was found in the detrital wood scatter in the reed peat (312). This appeared to be a birch bark roll but had a piece of moderately charred roundwood at its centre $(130 \times 17 \times 15 \mathrm{~mm})$, broken at both ends and also identified as aspen. There is no evidence of woodworking, although the item is twisted through a half turn along its length, somewhat reminiscent of a twisted withy. The roll contained charcoal and fragments of bark.

\section{The uncharred rolls}

The rolls which have not been charred may have been collected for tar production or the creation of torches at a later date. Alternatively, they may have been gathered for other purposes such as fishing floats (Robson et al. 2016). Ethnographic analogies (for example, Svensk uppslagsbok 1956, vol. 9:1112) have demonstrated that birch bark rolls were used as net floats in conjunction with fishing (Figure 30.11).

A number of sites have revealed evidence for net floats made of birch or pine bark: Friesack IV (Gramsch 1992; Robson 2016), Antrea Korpilahti in Russia, Riihimäki Sinivuokkoniemi in Finland (Koivisto 2011), Siivetsi in Estonia (Kriiska and Roio 2011), Sventoji 6 in Lithuania (Rimantiené 2005), Møllegabet II in Denmark (Skaarup and Grøn 2004), and Vis I in Russia (Burov 1989). At the inland peat bog site at Zamostje 2 in Russia, three fishing floats were recovered, two made from willow (Salix sp.) and the other from pine (Pinus sp.) bark. All three floats were egg shaped with a 'hole shifted to the end' (Lozovski et al. 2013, 31). Although absent at Star Carr, wooden discs with perforations have also been recovered from a number of Early to Late Mesolithic sites including: Holmegaard IV, Maglelyng (Troels-Smith 1960), Møllegabet I (Skaarup 1983) and Tybrind Vig (Andersen 2013) in Denmark; Rüde LA 2, Satrup LA 71 Förstermoor, Südensee LA 1b (Schwabedissen 1960; Feulner 2012), Grube-Rosenhof LA 58 (Hartz and Kraus 2009) and Hohen Viecheln (Schuldt 1961) in Germany; Veretye I in Russia (Oshibkina 1983); and Sventoji in Lithuania (Rimantiené 1979). 


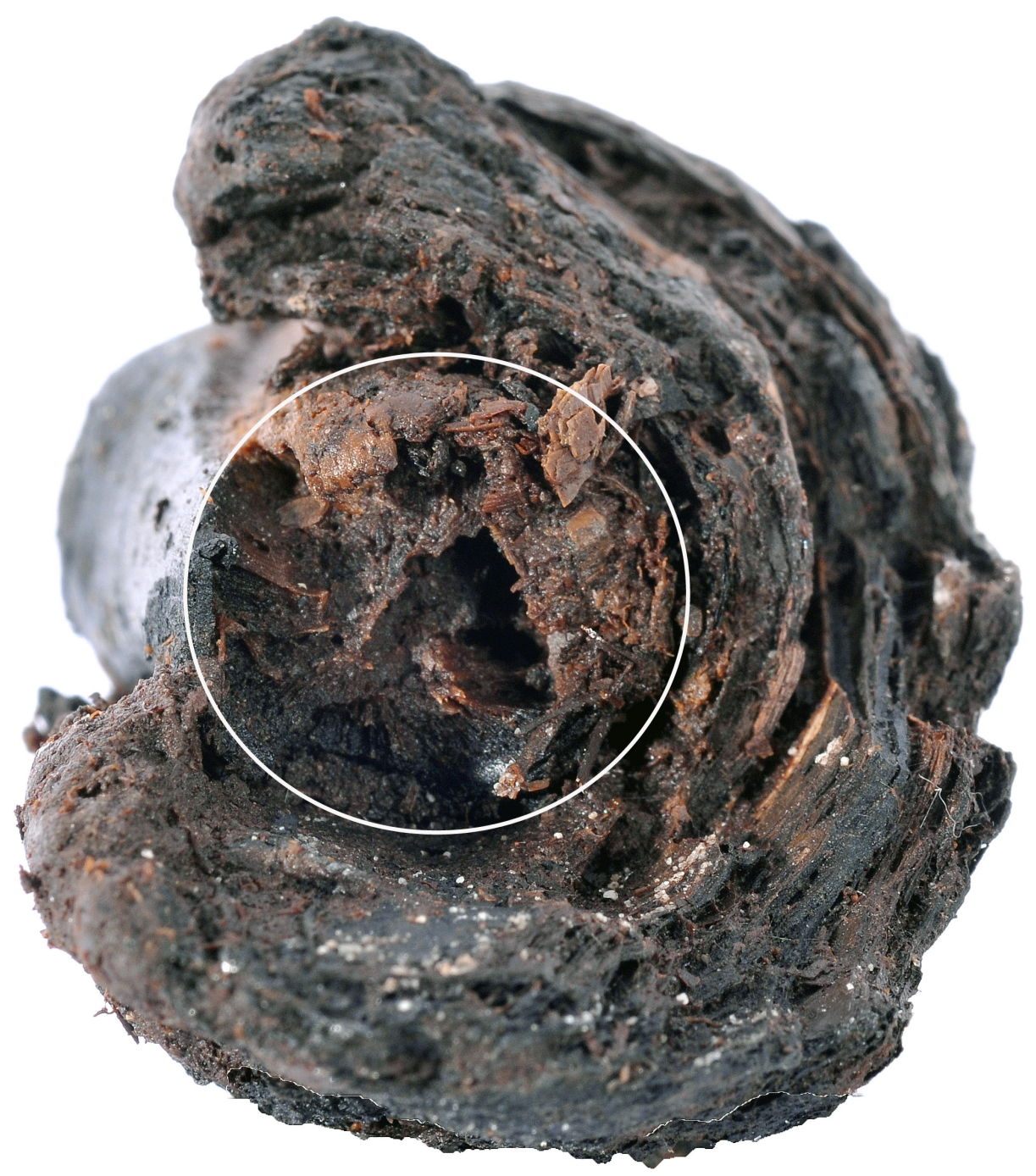

Figure 30.9: Side view of a composite torch $<115628>$. The wood stick is shown by the white ring and birch bark is wound around it. Both the stick and the bark are charred (Photograph taken by Paul Shields. Copyright University of York, CC BY-NC 4.0).

Figure 30.10: Illustration of composite torch $<115628>$ (Copyright Chloe Watson, CC BY-NC 4.0).
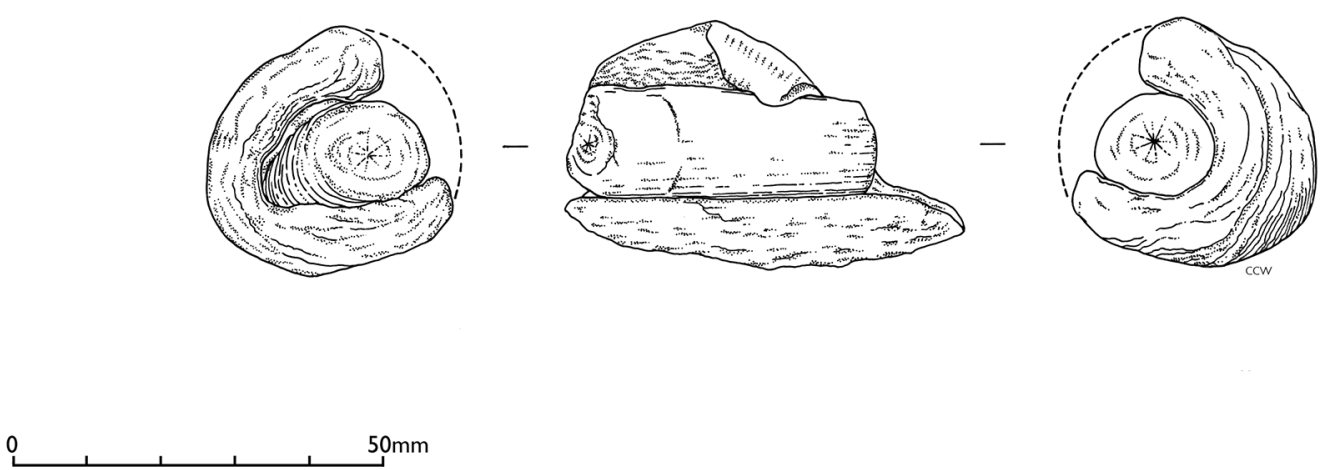


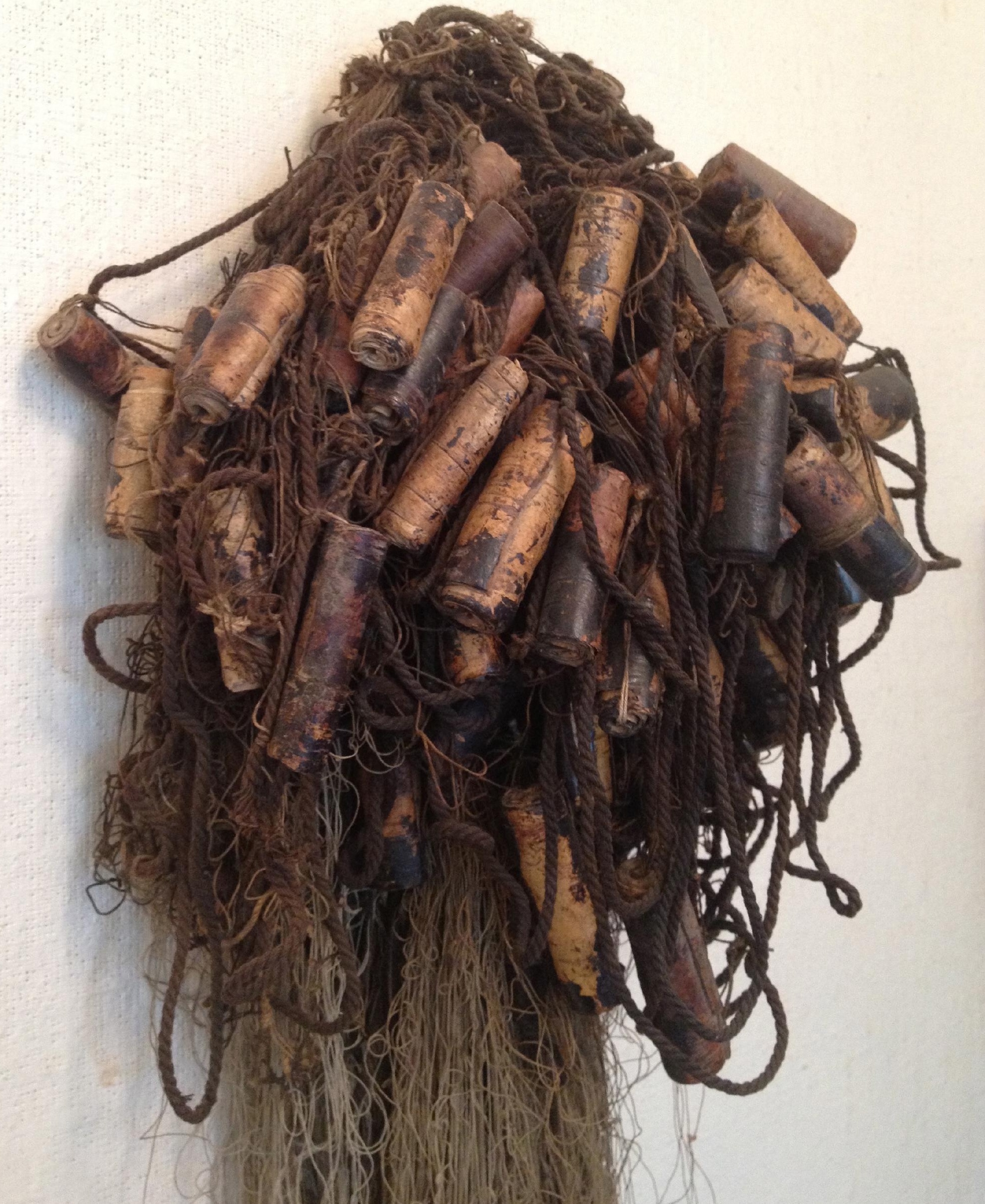




\section{European context}

Birch bark rolls have been found on a number of Early Mesolithic sites in Europe. In Denmark, excavations at the site of Mullerup Syd (Sarauw 1903) produced bark rolls made from a number of wood species including birch and hazel. Sarauw (1903) suggested that although some may be natural, one of the smaller rolls $(20 \times 8$ $\mathrm{mm}$ ) had a cut mark on it. At the Danish site of Ulkestrup Lyng at least two birch bark rolls were recovered from the floor layer (Andersen et al. 1982, Tauber 1971). At the Late Mesolithic Ertebølle site of Tybrind Vig a birch bark roll was found in mud deposits; four tightly fitted layers of thin bark ( $<0.5 \mathrm{~mm}$ thick) were found bound together, which were interpreted as being used for the production of birch tar (Andersen 2013). In Germany, at Friesack IV, numerous specimens were recovered including one which had resinous material (pitch) adhering to it, which may represent tar production, perhaps for hafting composite tools or use as a sealant (Gramsch 1992, 2016; Gramsch and Kloss 1989, 321; Gramsch 1992). Furthermore, a small number of birch bark rolls were recovered in the gyttia deposits at the Swedish Middle to Late Mesolithic site of Tågerup (Karsten and Knarrström 2003).

Based on these data, it would appear that birch bark rolls were used throughout the entire Mesolithic period in Northern Europe. In many cases, they are interpreted as being used for the manufacture of tar, which is also found at a number of sites, such as Ageröd V, Bökeberg and Segebro in Sweden (Larsson 1982, 1983; Karsten and Regnell 1995; Regnell et al. 1995) and Locality 17 and Øvre Storvatnet in Norway (Bang-Andersen 1989, 348). Broadly contemporaneous with Star Carr, the Early Mesolithic Maglemose sites of Barmosen I in Denmark and Huseby Klev in Sweden yielded numerous pieces of birch tar, some of which had human teeth impressions (Hernek and Nordqvist 1995; Johansson 1990). At Barmosen I, a total of 22 pieces were found. Of these, two had human teeth impressions (Johansson 1990). At Friesack IV, lumps and flat pieces of resin, some with teeth impressions, have also been found (Gramsch and Kloss 1989, 321; Gramsch 1992). Although lacking teeth impressions a number of 'resin lumps' or 'resin blocks' have been recovered from several Early Mesolithic sites, including Pulli in Estonia (Vahur et al. 2011) and Thatcham III and Lackford Heath in Britain (Hedges et al. 1994). Furthermore, birch bark tar, used as a hafting adhesive, has been identified on a number of different artefacts from several Mesolithic sites. At Ageröd V in Sweden at least four micro-blades had varying amounts of tar adhering to them (Larsson 1983), and in Rönneholms Mosse in Sweden, birch bark tar was found adhering to a wooden arrow (Larsson and Sjöström 2010; Larsson et al. forthcoming). Tar has also been identified on an unretouched stone tool from Thatcham III, Britain (Hedges et al. 1994), as well as a microlith from Holm Mølle, Denmark (Rysgaard et al. 2016), Pulli, Estonia (Vahur et al. 2011) and Seedorf, Germany (Aveling and Heron 1999). Lastly, it was also identified on seven barbed points from Friesack IV in Germany (Gramsch 2011).

\section{Experimental analysis}

\section{Rationale}

In order to test how and why some of these birch bark rolls have been charred, a number of experiments were carried out. In particular, we wanted to test a variety of different uses of birch bark rolls involving charring: tapers (used for lighting fires), torches and heating for tar extraction.

Tapers

A number of attempts were made by creating birch bark tapers out of thin strips of bark. The birch strip was lit at one end and although at first it started to burn, the flame died out seconds later. During a second attempt the

Figure 30.11 (page 431): Photograph of birch bark rolls used as fishing net floats at the Koguva Fishing Museum, Estonia (Copyright Harry Robson, CC BY-NC 4.0).

Figure 30.12 (page 433): Photograph of a lit torch made from rolled birch bark (Photograph by Aimée Little. Reprinted from Boreham et al. 2011b. Copyright (2011) with permission from Elsevier). 


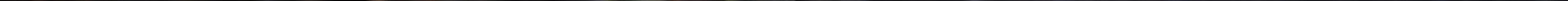


end of a small roll of birch bark was used. This also caught alight and continued to burn quickly whilst curling into a tighter roll. However, it too died out after a few seconds. Although this method did reproduce the same pattern of charred ends seen on the archaeological examples, it did not appear to be a very effective taper. It is possible that the bark was not dry enough, but even so, it is hard to see why birch bark would be used as tapers; if fires were blazing, a stick can be used more effectively to transfer fire, and if fires are being lit from scratch, it is better to use very fine bark material to get a fire to catch rather than a roll.

\section{Torches}

A number of different methods were used to produce a torch. The first simply involved wrapping a roll around a stick. To make the bark more pliable for rolling, it was first held over flames for a few seconds. Once rolled, it took several attempts to get it to catch fire, and even then it only burned for a few seconds, resulting in a small percentage of the outer birch bark roll being charred. It is likely that it did not burn well due to the restriction of airflow between each layer of the roll.

In order to improve the duration of burning, a second torch was made by placing dried leaves within the roll. Once again it was wrapped around a stick and staked into the ground. Again the torch only burned for a few seconds and then died out, leaving a charred outer surface. A further attempt was made by placing sticks and twigs between each layer of the roll, then wrapping the roll around a stick and staking it into the ground. This too was unsuccessful: the torch charred the outer bark roll and then burnt out. A variation on this attempt was tried using ripped layers of birch bark to make a roll, with linden bast fibre then wrapped around the roll and tied to a stake which was then placed in the ground. Although the torch burned, the dried materials fell out and the roll then unravelled.

Finally, rather than using fresh bark, old bark was used instead. These torches proved very successful, burning for almost ten minutes (Figure 30.12). It is likely that the success of these is that old birch bark does not curl up as tightly as fresh bark, which means air can circulate between the layers of the roll.

\section{Aceramic birch tar production}

The use of tar extracted from birch bark can be traced as far back as the Middle Palaeolithic (Mazza et al. 2006). As birch bark tar had previously been identified at Star Carr, it made sense to investigate whether birch bark rolls could have been used for this purpose, using an aceramic method of tar production (see Meijer and Pomstra 2011). A fire was built early in the morning and continually added to over the course of the day to sustain the fire and increase temperature. In the late afternoon, three birch rolls were placed upright into the ground underneath the fire and covered with soil and hot ashes (Figure 30.12). The fire was not placed directly over the top of the rolls but to the side. After 30 minutes, the rolls were inspected but they were not charred. The rolls were kept covered for another 15 minutes and then taken out of the ground one at a time. All three rolls were hot from the ashes and also very soft. The tops of each roll were charred. Each roll was unravelled and inside the centre of each one charring was visible and the bark had begun to turn to ash. We believe this attempt was unsuccessful because high wind and a damp autumn day had made it difficult to reach the high temperature required to produce tar. On another occasion, when weather conditions were favourable, the same experiment was repeated, reaching a maximum temperature of $570^{\circ} \mathrm{C}$. On this occasion we were able to produce tar, though not in any substantial quantity but enough to haft a couple of flint tools.

This low production of tar is interesting. As well as being dependent on weather conditions (though windbreaks may have been used, or even huts), it suggests that if these rolls were being used for this purpose, people probably made tar and stored it on sticks, to be reheated and used at a later date. It is also important to note that like the archaeological birch bark rolls, the replica rolls were also only partially burnt, typically at one end. This was not the case with the birch torches which burned away entirely. Thus, when burning patterns are compared, replica rolls used in tar production are more comparable with what is seen archaeologically. 
